\title{
Stress in the Higher Education Sector: Causes and Yoga-Mindfulness Interventions
}

\author{
Catherine Kelly* \\ University of Greenwich, London
}

Submission: July 19, 2017; Published: November 29, 2017

*Corresponding author: Catherine Kelly, University of Greenwich, Park Row, Se10 9LS, London, Email: C.kelly@gre.ac.uk

\begin{abstract}
The Aim of this paper was to critically review the nature and causes of stress among academics in higher education workplaces and to undertake a pilot study of how yoga-mindfulness interventions might help to address these issues. The background to this subject comprises an increase in reported levels of stress and stress-related absenteeism in university employees. Universities have changed considerably from workplaces once thought of as secure and relaxed contexts, to those facing considerable upheaval due to the erosion of resource bases, temporary contractual work, and multifaceted job roles and rising expectations. Whilst the topic of stress in educational workplaces is broad one, this paper focuses on the causes and sources of stress identified by a selection of key research articles. This focus allows for an in-depth initial understanding of why stress is an increasing problem in this sector.
\end{abstract}

The methods employed to undertake the first part of this work involved an extensive literature analysis. Key academic articles were selected using a range of inclusion and exclusion criteria. Studies were reviewed from across the developed world and many employed mixed qualitative and quantitative methodologies as part of their research. Databases used to select the final papers included the Cochrane library, Science Direct, Medline, PsychInfo, BMJ, Swetswise, Google Scholar, EPPI centre and Ebscho host. The methods employed for the second part of this work involved a pilot study survey assessing the perceived benefits of participation in a yoga-mindfulness based programme in a UK university.

The findings collated for this review show that majority of stress causes among academic staff stem from the 'external environment' or extrinsic sources; i.e. the 'organisation' itself and how it is managed. The most common key stressors were reductions in resources/financial constraints; workload pressures (including job expectations, time constraints and increased administrative loads); job insecurity/contracts; 'management' styles and policies; and workplace relationships (issues with staff-management interfaces, unmotivated colleagues, and workload disparities). Interestingly, stressors concerned with 'core' functions of academics, those of teaching and student demands did not rank highly in most cases. Intrinsic causes of stress were related to issues of reward and recognition; increased lack of individual control; promotional prospects and maintaining a good work-life balance. Various differences were reported on correlations between the above stressors and variables such as age, gender, length of employment. The pilot study of the YMBI (Yoga-Mindfulness Based Intervention) indicated that there was a strong positive effect on individual's perceived levels of personal coping abilities during the programme. This indicates a growing need for structural inclusion of targeted prevention as well as individual intervention strategies for stress management among faculty in universities. More work is needed on the relationship between stress in Higher Education and effective mind-body work-based interventions.

Keywords: Stress; Causes; Higher education; Universities; Yoga; Mindfulness; Interventions; Wellbeing

\section{Introduction}

This research is contextualised within the broad field of Stress Management which encompasses multiple disciplines including Psychology, Health, Complementary and Alternative Medicine, Educational research, Management and Organizational Behaviour, amongst others. Approaches to the subject of 'stress' in the literature ranges from definitional discussions, analysis of causal factors, physical and psychological manifestations of stress, its impacts and organisational interventions. This work focuses on the higher education, tertiary or university sector (variously named in different countries) and forms an initial part of a wider study. This first stage examines in detail, using secondary sources, the key identified causes of stress in the sector, and then offers an initial pilot study that examines a yoga-mindfulness based intervention in one Higher Education Institution (HEI).

\section{Stress in the Education Sector}

The concept of stress is a much debated issue in contemporary society. The difficulty in specifying exact definitional parameters comes perhaps from the fact that stress is both a physiological and a psychological matter. This implies that stress means 
different things to different people and also manifests itself in varying ways $[1,2]$. Seminal research on stress was conducted by Hans Seyle [3], (the General Adaptation Syndrome) and this has set the baseline for subsequent research. He examined stress in relation to its effects on the body and its immune system, thereby creating the field of psychoimmunology. His concepts were problematic because he felt that stress depended only on the intensity of the stressor. Other, later work, by Lazarus [4] introduced a cognitive element to the debate citing the importance of the mind's perception of what stress is. Cooper \& Palmer [5] adapt a useful working definition that also emphasises the psychological context, noting that "stress occurs when pressure exceeds [one's] perceived ability to cope".

The causes of stress can be attributed to both Instrinsic (individual level) and Extrinsic (external) factors, Greenberg [6], and these will be examined in more detail in the literature review that follows. Intrinsic causative stress factors include the personality of an individual and their inherent ability to cope with/respond to stress. Research by Friedman \& Rosenman [7] into personality types indicates the commonly quoted 'Type A and Type B' personalities-competitive/relaxed respectively. Critics of personality classifications however, note that many people often do not fit into neat categories [8]. Extrinsic causative stress factors refers to the context in which the individual operates, and may include work-related stress, worklife imbalance, family problems and illness, and it is these on which this research primarily focuses.

The case studies for this research involves work based stress. Much has been written on stress in the workplace especially around organisational behaviour, employee relations and workrelated illness [9-12]. In particular, the higher education sector is the workplace environment under scrutiny here. Traditionally, universities have been regarded as low stress working environments but recent changes in government funding, contract and personnel practices, as well as changing workloads and expectations have meant that academic employees face multiple challenges that did not exist in the past [13]. Gillespie et al. [14] further emphasise changes in the perceived advantages of academic employment, noting that academic salaries have fallen in real terms, many positions are now untenured, workloads have increased, academics are facing increasing pressure to be responsible for university rankings or league tables, to attract research funding and to 'publish or perish'.

To cross-contextualise generic research on the causative factors for stress (see above), Tytherleigh et al. [15] refer to previous research that suggests academics are intrinsically motivated by their disciplines and related teaching and research tasks, but extrinsically de-motivated by work context factors such as insufficient resources and funding and poor management practices. This work aims to draw together a focused body of research on the causes of stress in academic workplaces, and provide a solid, evidence-based platform from which to better understand this timely subject matter.

\section{Materials and Methods}

\section{Stress causes literature analysis}

Because of this potential breadth of this study, a deliberate decision was taken to focus here primarily on the causes of stress- and specifically amongst academic staff working in the higher education sector as the main aim of the project. An indepth understanding can be gained by studying comparative international studies. The key secondary literature review research question for this work therefore, was:

'What are the main causes of stress among academic employees in Higher Education'?

Studies selected-an overview: Studies chosen for this project focused on occupational stress among employees of further education academic institutes. Table 1 shows that some studies focused entirely on academic employees [16], whilst others mixed both academic and administrative staff [17]. For the latter, only the academic aspect was extracted for analysis here, given the aim of the project. All studies examined the causes of stress, but some went further and examined impacts and subsequent interventions. Again, the 'causes' factor was extracted for the purpose of this work to maintain a focused study. The 12 studies comprised of four from the United Kingdom, three from the United States, two from Australia, one from the Philippines, one from South Africa and a comparative analysis of China and Japan. This gave a well rounded approach to cultural and geographical difference that contributed to wider understanding of stress causes in different academic contexts. The aim here was to acknowledge that different locational conditions can perhaps cause different experiences of stress among academics. The studies were heterogeneous with respect to methodologies adopted and included multivariate modelling, questionnaire surveys, focus groups and diaries. The highest number of respondents for a single survey was 3808, and the lowest was 158. In total, the studies chosen surveyed over 10,000 respondents and this was felt to be a good representation of the sector for the research question posed.

\section{Yoga-mindfulness based intervention analysis}

A UK university known to the researcher was selected for a pilot study on a YMBI that lasted 6 weeks in duration. The wellbeing service of the university advertised a yoga- 
mindfulness programme open to all staff who felt they would benefit. It took place at lunchtimes, mid-week, on campus and had 30 self-signed up participants, all of whom agreed to take part in the study. All completed a pre and post-intervention survey using the Warwick Edinburgh approach for a mental wellness questionnaire, as well additional survey questions that investigated specific work-related stressors. The WarwickEdinburgh Mental Well-being scale was developed to enable the

Table 1: List of 12 key studies used in this review. monitoring of mental wellbeing in the general population and the evaluation of projects, programmes and policies which aim to improve mental wellbeing. 'The 'WEMWBS' is a 14 item scale with 5 response categories, summed to provide a single score ranging from 14-70. The items are all worded positively and cover both feeling and functioning aspects of mental wellbeing. See Table 2 below:

\begin{tabular}{|c|c|c|}
\hline$[13]$ & 2001 & Occupational stress in university staff \\
\hline$[14]$ & 2001 & Occupational stress in universities: staff perceptions of the causes, consequences and moderators of stress \\
\hline$[15]$ & 2005 & Occupational stress in UK higher education institutions: a comparative study of all staff categories \\
\hline$[16]$ & 2000 & A Comparative study of stress among university faculty in China and Japan \\
\hline$[17]$ & 2004 & Stressors and stress reactions among university personnel \\
\hline$[22]$ & 2003 & Running up the down escalator: stressors and strains in UK academics \\
\hline$[27]$ & 1996 & Stress, coping strategies and job satisfaction in university academic staff \\
\hline$[28]$ & 1986 & Dimensions of stress among university faculty: factor analytic results from a national study \\
\hline$[29]$ & 2007 & Gender, health and stress in english university staff-exposure or vulnerability? \\
\hline$[31]$ & {$[2016]$} & Causes and effects of stress among faculty members in a state university. \\
\hline$[32]$ & 2008 & Occupational stress of academic staff in south african higher education institutions \\
\hline
\end{tabular}

Table 2: The Warwick-Edinburgh Mental Wellbeing Scale.

\begin{tabular}{|c|c|}
\hline WEMB Questions & *Scores Per Question Answer \\
\hline $\begin{array}{l}\text { 1. I've been feeling optimistic about the future } \\
\text { 2. I've been feeling useful } \\
\text { 3. I've been feeling relaxed } \\
\text { 4. I've been feeling interested in other people } \\
\text { 5. I've had energy to spare } \\
\text { 6. I've been dealing with problems well } \\
\text { 7. I've been thinking clearly } \\
\text { 8. I've been feeling good about myself } \\
\text { 9. I've been feeling close to other people } \\
\text { 10. I've been feeling confident } \\
\text { 11. I've been able to make up my own mind about things } \\
\text { 12. I've been feeling loved } \\
\text { 13. I've been interested in new things } \\
14 . \text { I've been feeling cheerful } \\
\text { (*ach question is scored } 1-5 \text { by the participant, then totalled) }\end{array}$ & $\begin{array}{l}\text { c) Some of the time ( } 3 \text { points) } \\
\text { d) Often ( } 4 \text { points) } \\
\text { e) All of the time ( } 5 \text { points) }\end{array}$ \\
\hline
\end{tabular}




\begin{tabular}{|c|c|}
\hline Results & '5-Ways to Wellbeing' Suggested Actions \\
\hline $\begin{array}{l}\text {-32 points } \\
\text { Your wellbeing score is very low. } \\
32-40 \text { points } \\
\text { Your wellbeing score is below average. } \\
40-59 \text { points } \\
\text { Your wellbeing score is average. } \\
59-70 \text { points } \\
\text { Good news, your wellbeing score is above average. } \\
\text { Continue doing the things that are keeping you happy. }\end{array}$ & $\begin{array}{l}\text { Most people have a score between } 41 \text { and } 59 \text {. You may want to begin by talking to } \\
\text { a friend or health professional about how you can start to address this. } \\
\text { There are five evidence-based steps we can all take to improve our mental } \\
\text { wellbeing. They are: } \\
\text { 1. Get active } \\
\text { 2. } \\
\text { 3. } \\
\text { Kennect with others } \\
\text { 5. } \\
\text { Be awarning of yourself and the world } \\
\text { (NHS UK, 2016) }\end{array}$ \\
\hline
\end{tabular}

An additional 4 questions were also asked to participants:

a) What things cause you the most stress at work?

b) Do you feel supported by your workplace to deal with or communicate this stress? (Please explain);

c) What could your institution do to help with stress management, and

d) Why are you partaking in this programme?

An additional 2 questions were added in the post-programme survey, namely

(i) What effect has this programme had on your stress levels at work?

(ii) Can you say what specifically you found effective/ ineffective?

The 6 week programme of yoga-mindfulness was delivered by an outside provider to university staff, and used a combination of Hatha Yoga postures (strengthening and calming) with mindfulness-based stress reduction techniques, as developed by Kabat Zinn [18], an effective evidence based programme centred on meditation, being intentionally 'present', in the moment, and without unhelpful judge mentalism. Self-regulation is also a core mechanism in the process Hart et al. [19]. Breath work formed a central part of the programme, with start and finish sequences focused on calming the breath and becoming aware of its role and assistance in calming the individual.

Yoga research has become more main stream in academic studies, and the health benefits are evident. In a systematic review of almost 500 articles/studies on the benefits of yoga Elwy et al. [20] 40\% mention the physiological benefits of yoga, such as heart rate, blood pressure and hormone levels, $26 \%$ relate to physical functioning such as chronic pain and arthritis, 25\% examine mental and emotional health outcomes, including anxiety, depression and stress, while 6\% focused on general wellbeing, such as quality of life or mindfulness and just 3\% examined the workplace and yoga, in relation to employee satisfaction and fatigue, Smith \& Sziva [21]. Given the overall increasing evidence for the effectiveness of both yoga and mindfulness, this paper investigates a pilot study within a Higher Education Institute (HEI) setting, having first examined stress causes in this sector.

\section{Findings}

Each of the 2 parts of this research will be presented separately and then discussed collectively in the following section.

\section{Causes of stress in HE literature analysis results}

This section presents the 'main evidence' of all articles reviewed in an integrative, collective critique of content, methodology and findings. Key content is examined and an evaluation of methods is undertaken supported by research methods literature. An overview of key trends emerging in this academic stress literature is thus presented. This review focuses on the causes of stress in higher education academics. Much research has been conducted on the effects, impacts and management interventions of stress in this and other workplace environments $[6,11,22]$. The scope of this project however was limited in time and length and therefore a focused approach was adapted, to present key evidence on stress causes (or 'sources'), specifically. Gillespie et al. [14] begin their study by echoing the work of Lazarus [23] and Folkman \& Gruen [24] and conceptualise stress as a complex, multivariate process, resulting from a broad system of variables involving inputs, outputs and the mediating activities of appraisal and coping. They go on to state that 'according to this transactional approach, the stress process is dynamic and constantly changing as a result of the continual interplay between person and environment' [14]. This position is one which forms an important tenet for the way in which this literature review project approaches the subject at hand. An AUT [25] study in the UK on academic stress reported that $93 \%$ of its members (0ver 160,000 academics) experienced stress at work, 
whilst an earlier study in New Zealand reported an $80 \%$ rise in workload stress amongst HEI academics [26]. Although it can be argued that such data represent only a selection of all academics, the trend is still significant and worthy of further investigation. Abouserie [27] notes that academics and researchers spend considerable amounts of their times studying other groups, but seldom take time to examine their own profession, and citing Gmelch et al. [28] observes that academics are to education as goldfish are to water- they swim in the water but often fail to study it. 12 studies were selected for inclusion in this work, (all of which examined stress causes) in HEIs as places of work. Studies selected were heterogeneous with regard to comparison groups, scale and cause-effect measures, therefore no attempts are made to combine results for detailed meta-analysis of the findings. A full 'content-analysis summary' (CAS) of each research article was created, comprising: author, title, background, participants, stress cause findings, methodologies, responses, conclusions and critique - see Figure 1 for an example.

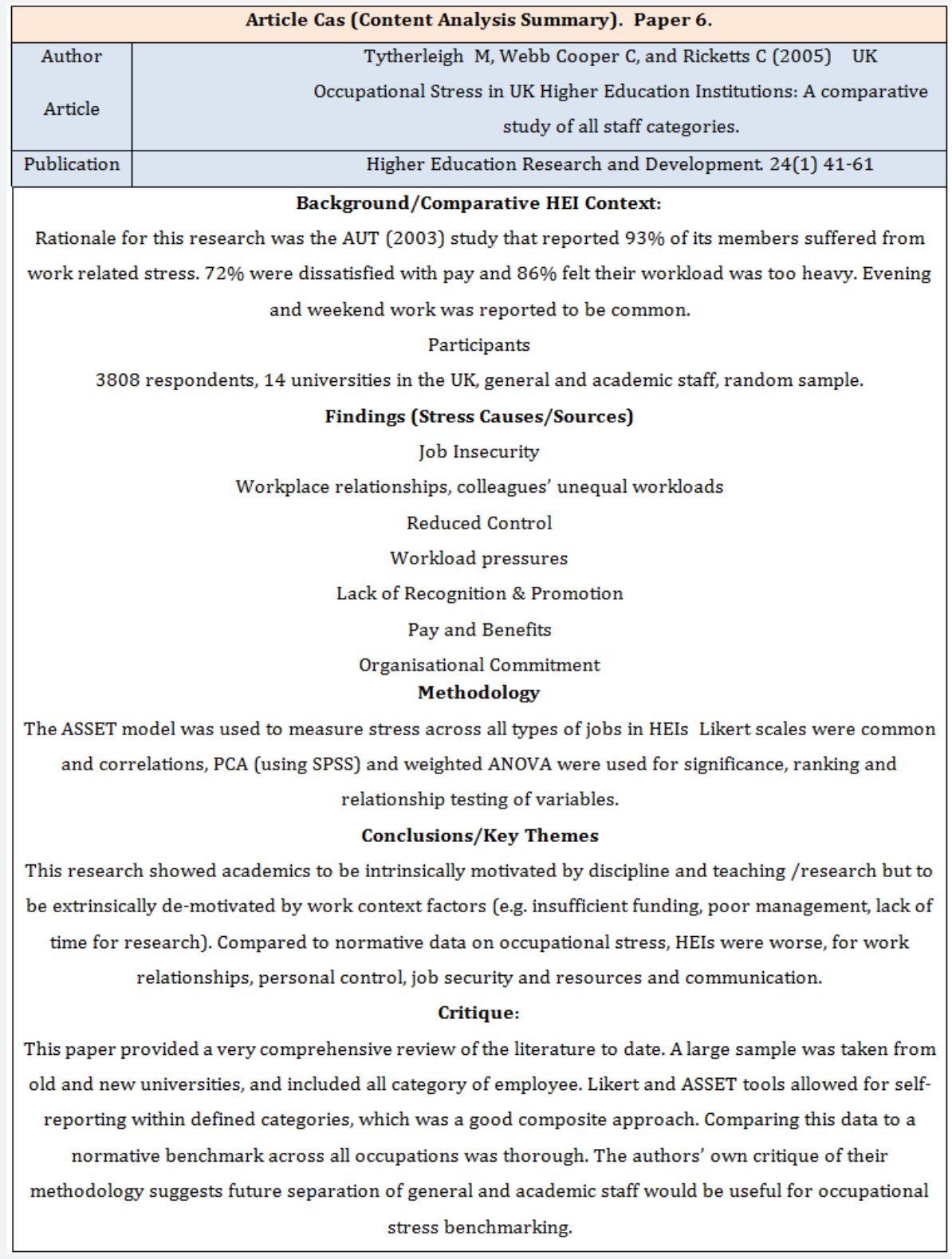

Figure 1: Sample CAS. (of one of the 12 Studies used).

Participants: Over 10,000 respondents working in over 140 different HEIs across 6 countries participated in the 11 studies selected. The majority of the research took place in the UK, Australia and the United States. Where studies combined both general and academic employees, findings on the latter only were analysed where disaggregation was evident.

Comparative HEI environments and contexts: Most of the 12 studies began with a review of prior research on HEI 
stress, often quoting each others' previous own works. Key collective trends from the selected articles showed that in the UK academic work environments were characterised by a move to mass higher education Kinman \& Jones [22], thus representing a more profound re-orientation than any other system in industrial societies. Heavy workloads, evening and weekend work, dissatisfaction with pay Tytherleigh et al. [15], multi-tasking a plethora of roles, Abouserie [27] and gender inequalities Tytherleigh et al. [29], all provided a backdrop to the research reviewed here. The Australian studies also reiterated the multiple teaching, administrative and research responsibilities as an increasing role change, Gillespie et al. [14], whilst lower levels of autonomy and increased contractual instability were features of Southern hemisphere work environments [13]. In the USA rising levels of stress have been reported over the past 15 years among HEI academics, Hogan et al. [17], who also observe that academic stress in particular, is high compared to other occupations in the US. Brix \& Cruise [30] contextualise university teacher stress in terms of how well matched workers' needs are with the demands of the job they carry out, and they note how this has changed over time. Gmelch et al. [28] echo the other geographic regions studied in possible stressors for academic employees.

Table 3: Key findings of article reviews: causes and sources of stress among HEl academics.

\begin{tabular}{|c|c|c|c|}
\hline Cause & Author/Study & Classification & $\begin{array}{c}\text { Code (Internal or External } \\
\text { Environment) }\end{array}$ \\
\hline Poor Promotional Prospects & Winefield \& Jarrett [13] & Organisational-HR & EE \\
\hline University Management & Winefield \& Jarrett [13] & Organisational-Management & $\mathrm{EE}$ \\
\hline Contract Types & Winefield \& Jarrett [13] & Organisational-HR & $\mathrm{EE}$ \\
\hline Funding & Winefield \& Jarrett [13] & Organisational-Financial & $\mathrm{EE}$ \\
\hline Reduced Autonomy / Control & Winefield \& Jarrett [13] & $\begin{array}{l}\text { Organisational-Individual } \\
\text { Autonomy }\end{array}$ & EE-IE \\
\hline Funding and Resources & Gillespie et al. [14] & Organisational-Financial & $\mathrm{EE}$ \\
\hline Work Overload & Gillespie et al. [14] & Organisational-Workload & $\mathrm{EE}$ \\
\hline Poor Management & Gillespie et al. [14] & Organisational-Management & $\mathrm{EE}$ \\
\hline Job Insecurity & Gillespie et al. [14] & Organisational-Human Resource & EE/Macro EE \\
\hline Insufficient Reward \& Recognition & Gillespie et al. [14] & $\begin{array}{l}\text { Organisational-Individual } \\
\text { Interface }\end{array}$ & EE-IE \\
\hline $\begin{array}{c}\text { Decreased Levels of Individual } \\
\text { Control }\end{array}$ & Gillespie et al. [14] & $\begin{array}{l}\text { Organisational-Individual } \\
\text { Autonomy }\end{array}$ & EE-IE \\
\hline Job Insecurity & Tytherleigh et al. [15] & Organisational-HR & $\mathrm{EE}$ \\
\hline $\begin{array}{l}\text { Workplace relationships, } \\
\text { colleagues' unequal workloads }\end{array}$ & Tytherleigh et al. [15] & $\begin{array}{c}\text { Organisational-Workloads } \\
\text { Organisational-Workplace } \\
\text { Relationships }\end{array}$ & EE \\
\hline
\end{tabular}




\section{Journal of Yoga and Physiotherapy}

\begin{tabular}{|c|c|c|c|}
\hline Reduced Control & Tytherleigh et al. [15] & $\begin{array}{l}\text { Organisational-Individual } \\
\text { Autonomy }\end{array}$ & EE-IE \\
\hline Workload pressures & Tytherleigh et al. [15] & Organisational-Workloads & $\mathrm{EE}(/ \mathrm{IE})$ \\
\hline Lack of Recognition \& Promotion & Tytherleigh et al. [15] & Organisational-Management-HR & $\mathrm{EE}$ \\
\hline Pay and Benefits & Tytherleigh et al. [15] & Organisational-HR-Financial & $\mathrm{EE}$ \\
\hline Organisational Commitment & Tytherleigh et al. [15] & Organisational-Management & EE \\
\hline $\begin{array}{c}\text { Professional Evaluation and } \\
\text { Appraisal }\end{array}$ & He et al. [16] & Organisational-Management-HR & $\mathrm{EE}$ \\
\hline Time pressures & He et al. [16] & $\begin{array}{l}\text { Organisational-Workloads/ } \\
\text { Multiple Roles }\end{array}$ & EE \\
\hline Academic Identity & He et al. [16] & Individual-Organisation Interface & $\mathrm{IE} / \mathrm{EE}$ \\
\hline Work-Life Issues & He et al. [16] & Individual-Organisation Interface & $\mathrm{IE} / \mathrm{EE}$ \\
\hline $\begin{array}{l}\text { Macro-level State changes in } \\
\text { Sector }\end{array}$ & He et al. [16] & Organisation-Wider Economy & EE \\
\hline Job Pressure & Hogan et al. [17] & Organisational-Workloads & $\mathrm{EE}(/ \mathrm{IE})$ \\
\hline $\begin{array}{l}\text { Workloads and lack of Org. } \\
\text { Support }\end{array}$ & Hogan et al. [17] & Organisational-Workloads & $\mathrm{EE}$ \\
\hline Frequent Interruptions & Hogan et al. [17] & $\begin{array}{l}\text { Organisational-Workloads/ } \\
\text { Multiple Roles }\end{array}$ & $\mathrm{EE}$ \\
\hline Deadlines & Hogan et al. [17] & Organisational-Workloads & $\mathrm{EE}$ \\
\hline Paperwork increase & Hogan et al. [17] & $\begin{array}{l}\text { Organisational-Workloads/ } \\
\text { Multiple Roles }\end{array}$ & $\mathrm{EE}$ \\
\hline Salary Issues & Hogan et al. [17] & Organisational-HR-Financial & $\mathrm{EE}$ \\
\hline Workload imbalances & Hogan et al. [17] & Organisational-Workloads & $\mathrm{EE}$ \\
\hline Staffing and Resources & Hogan et al. [17] & Organisational-HR-Financial & $\mathrm{EE}$ \\
\hline $\begin{array}{c}\text { Non Job-description tasks } \\
\text { expectations }\end{array}$ & Hogan et al. [17] & Organisational-Workloads & EE \\
\hline Covering for Co-workers & Hogan et al. [17] & $\begin{array}{c}\text { Organisational-Workloads } \\
\text { Organisational-Workplace } \\
\text { Relationships }\end{array}$ & $\mathrm{EE}$ \\
\hline Unmotivated Co-workers & Hogan et al. [17] & $\begin{array}{c}\text { Organisational-Workloads } \\
\text { Organisational-Workplace } \\
\text { Relationships }\end{array}$ & $\mathrm{EE}$ \\
\hline Poor Management & Hogan et al. [17] & Organisational-Management & $\mathrm{EE}$ \\
\hline Promotional Opportunities & Hogan et al. [17] & Organisational-HR & $\mathrm{EE}$ \\
\hline $\begin{array}{l}\text { Rushed Pace of Work, Time } \\
\text { pressures }\end{array}$ & Kinman \& Jones [22] & Organisational-Management-HR & \\
\hline Frequent Interruptions & Kinman \& Jones [22] & $\begin{array}{l}\text { Organisational-Workloads/ } \\
\text { Multiple Roles }\end{array}$ & $\mathrm{EE}$ \\
\hline
\end{tabular}




\begin{tabular}{|c|c|c|c|}
\hline Work-Life Issues & Abouserie [27] & Individual-Organisation Interface & $\mathrm{IE} / \mathrm{EE}$ \\
\hline $\begin{array}{l}\text { Research Funding and } \\
\text { Competition }\end{array}$ & Abouserie [27] & $\begin{array}{l}\text { Organisational-Workloads- } \\
\text { Finances }\end{array}$ & EE \\
\hline Time Pressure & Abouserie [27] & Organisational-Workloads & $\mathrm{EE}(/ \mathrm{IE})$ \\
\hline Workplace Relationships & Abouserie [27] & $\begin{array}{l}\text { Organisational-Workplace } \\
\text { Relationships }\end{array}$ & $\mathrm{EE} / \mathrm{IE}$ \\
\hline Teaching and Student Demands & Abouserie [27] & Organisational-Workloads & $\mathrm{EE}(/ \mathrm{IE})$ \\
\hline Admin and Bureaucracy & Abouserie [27] & $\begin{array}{l}\text { Organisational-Workloads/ } \\
\text { Multiple Roles }\end{array}$ & $\mathrm{EE}$ \\
\hline Reward and Recognition & Gmelch et al. [28] & Organisation-Management & $\mathrm{EE}$ \\
\hline Time Issues & Gmelch et al. [28] & Organisational-Workloads & $\mathrm{EE}(/ \mathrm{IE})$ \\
\hline Departmental Influences & Gmelch et al. [28] & Organisation-Management & $\mathrm{EE}$ \\
\hline $\begin{array}{l}\text { Professional Identity, } \\
\text { Expectations, Research }\end{array}$ & Gmelch et al. [28] & $\begin{array}{l}\text { Individual-Organisational- } \\
\text { Workloads }\end{array}$ & $\mathrm{EE}(/ \mathrm{IE})$ \\
\hline Student Interactions & Gmelch et al. [28] & Organisation-Job Content & EE \\
\hline Poor Pay and Benefits & Tytherleigh et al. [29] & Organisational-HR-Financial & $\mathrm{EE}$ \\
\hline Work Relationships & Tytherleigh et al. [29] & $\begin{array}{l}\text { Organisational-Workplace } \\
\text { Relationships }\end{array}$ & $\mathrm{EE} / \mathrm{IE}$ \\
\hline Poor Job Satisfaction & Tytherleigh et al. [29] & $\begin{array}{l}\text { Organisational-Individual } \\
\text { Interface }\end{array}$ & EE-IE \\
\hline $\begin{array}{l}\text { Motivational Style (mis)Fit with } \\
\text { Work Environment }\end{array}$ & Brix \& Cruise [30] & Individual-Organisation Interface & $\mathrm{IE} / \mathrm{EE}$ \\
\hline Increased Paperwork & Colacion Quiros \& Gemora [31] & $\begin{array}{l}\text { Organisational-Workloads/ } \\
\text { Multiple Roles }\end{array}$ & $\mathrm{EE}$ \\
\hline Job overtakes personal life & Colacion Quiros \& Gemora [31] & $\begin{array}{l}\text { Organisational-Workloads/Work- } \\
\text { life Balance }\end{array}$ & $\mathrm{EE} / \mathrm{IE}$ \\
\hline Workplace Relationships & Barkuizen \& Rothman [32] & $\begin{array}{c}\text { Organisational-Workloads } \\
\text { Organisational-Workplace } \\
\text { Relationships }\end{array}$ & $\mathrm{EE}$ \\
\hline Workload Balance & Barkuizen \& Rothman [32] & Organisational-Workloads & $\mathrm{EE}(/ \mathrm{IE})$ \\
\hline Time Pressures & Barkuizen \& Rothman [32] & Organisational-Workloads & $\mathrm{EE}(/ \mathrm{IE})$ \\
\hline Job Security & Barkuizen \& Rothman [32] & Organisational-Management-HR & EE \\
\hline Individual Autonomy Decline & Barkuizen \& Rothman [32] & $\begin{array}{l}\text { Organisational-Individual } \\
\text { Autonomy }\end{array}$ & EE-IE \\
\hline Resources and Communications & Barkuizen \& Rothman [32] & $\begin{array}{l}\text { Organisational-Management- } \\
\text { Financial }\end{array}$ & $\mathrm{EE}$ \\
\hline
\end{tabular}

Causes and sources of stress (summary and classification of main research findings): All of the selected papers were analysed closely with regard to their key findings of stress causes. In some instances, these results formed part of wider studies. The collective causes (sometimes phrased as

'sources') of stress across all of the studies were collated and Table 3 summarises these key findings. This summary is a key element that addresses the research question for this project. Content Analysis was undertaken here to both synthesise and filter groupings of these reported findings amongst the papers 
reviewed. Content Analysis is used as a means of organising and making sense of material and can be applied to any written material [33]. Common themes appear throughout all of these studies and codes or categories were devised by the researcher, and also assigned to whether the cause lay with the external environment (EE) - i.e. the organisation or other factors beyond personal control, or the internal environment (IE)-issues to do with personal characteristics, health, gender, age, family, and work-life balance. It could be argued therefore, that the key causes of stress across all papers can be attributed primarily to:

a. Organisational Management Practices (including 'commitment' and communication)

b. Organisational Personnel/Human Resources Policies (on Contracts/Tenure and Promotions)

c. Organisational Financial Resourcing (capital, pay rates, personnel and research)

d. Organisational Workload Expectations, Multiplicity of roles, Imbalances and Overload

e. Diminishing levels of autonomy, control and decisionmaking

f. Workplace Relationship Challenges (unmotivated coworkers, covering for others)

g. Increased Administration Duties

h. Time Management Challenges (deadlines, pressures)

i. Student Demands and Interactions

j. Individual lack of recognition and reward

k. Work-Life Balancing

l. General Job Dissatisfaction and perceived reduction in professionalism

The conceptual framework for this review suggests stress causes that are internal to the individual's life, or external (institutional). Based on this content analysis, it can be argued that the majority of the causes of stress reported by respondents are Organisational in nature, and therefore correspond to 'the external environment', i.e. factors beyond the direct control of the individual. Internal environment factors such as their personal traits were not widely reported on in the studies, apart from basic demographic data such as gender and age. These are reviewed below. Perceptions of stress were researched by some authors and these are noted in the methodology discussion. Stress at an individual level varied across the samples, but decreasing levels of personal control in a profession once characterised by high levels of autonomy, was a widely reported source. According to Karasek's [34] Demand-Control theory of job stress, jobs with high levels of control should not be stressful even if those jobs are demanding. However, Winefield \& Jarrett's [13] research notes that HEI sector employment has shifted considerably to one characterised by high demands and lower than ever levels of autonomy.

Women were more vulnerable to workplace relationships as a source of individual stress, Tytherleigh et al. [29], while male respondents worried about pay and contracts to a greater extent [17]. Other personal stressors included the somewhat abstract concept of 'identity' and status [16]. The idea that one's professional status was being eroded caused concern. Other results showed stress relating to the reduction in time for 'scholarly activities' such as research [22]. Extrapolating some of these ideas, it seems apparent that multiple roles and working beyond one's exact job description is leading to reduced quality at many levels, and this causes stress to those employees who feel they cannot do their jobs well or to the standard they would prefer.

In terms of wider university systems and structures, new universities were found to have more stress attributed to workplace relationships and to have lower overall levels of job satisfaction (based on a sample of almost 2000 respondents in 8 'old' and 5 'new' universities in the UK, researched by Tytherleigh et al. [29]. Changing macro level structures in China have placespecific unique stress sources for He et al. [16] study, where an interesting observation can be made about the importance of changing political systems and their impacts on HEIs.

Responses to Stress: Although not a key focus for this initial review, it is of relevance to note some of the reported responses to the causes of stress in HEIs collated above. This allows for a more targeted interpretation of how cause and effect can be acted upon by management strategies in the future, and helped to inform the pilot study YMBI programme in the $2^{\text {nd }}$ part of this study. To summarise, key responses across the studies included:

a. Negative effects on professional work and personal welfare (G)

b. 'Closing down', where employees put less effort into their work, lower productivity $(\mathrm{G}, \mathrm{T}, \mathrm{H})$

c. Poor physical and psychological health $(G, T, H)$

d. Reduced job satisfaction (H, WJ)

e. Consider resignation (KJ)

f. Adoption of coping/survival strategies,- individual or organisational $(G)$

(Note: G =Gillespie et al. [14]; T=Tytherleigh et al. [29]; $\mathrm{H}=$ Hogan et al. [17]; WJ=Winefield \& Jarrett [13]; KJ= Kinman \& Jones [22]). 
It is somewhat of a challenge to summarise and make generalisations on the above given the wide diversity of studies selected and the heterogeneous samples and methodologies. What is important however, is to glean a sense of 'what is happening' in this sector and why stress is such a large factor in the employment experiences of HEI workers.

Summary of findings from the studies/the researcher's interpretation (of these) show that:

a. Organisation structures and function cause the majority of perceived stresses among HEI employees.

b. Academics are usually found to be more stressed than general or administrative staff.

c. Some studies showed no difference in gender and stress whilst others did. There is some suggestion that vulnerability to certain (similar) stressors presents differently in men and women, rather than differential levels of exposure to those same stressors [29].

d. Similarly, age was differentially reported be to a contributing factor, with younger staff reporting higher stress levels than older, more senior and more experienced academics.

e. Many of the studies showed a high degree of concurrence between HEI occupational stress causes and national occupational stress surveys conducted across all sectors in many of the countries studied. Exceptions included those related to factors such as professional identity, scholarly activity and student demand/relationships. Compared to normative data on UK occupational stress, HEIs were worse off in relation to stress sources concerning workplace relationships, personal control, job security, resources and communications [15]. Gmelch et al. [28] observe comparative HEI/normative occupational stressors in the USA are differentiated by stressors concerning reward and recognition, professional identity and student interactions.

f. In China, 'social transformation stress' was a unique, macro-level stressor manifested in serious changes to socioeconomic structures over time.

g. Stress causes a diverse range of effects at personal and institutional levels including individual poor health, absenteeism, reduced job satisfaction and commitment levels, and overall poorer quality work practices and worker experiences.

Despite the studies variability in their methodological approach and validity, it could be argued that larger samples that report on the causative aspects of stress in HEIs would be beneficial. Similarly, whilst single institution studies are important for in-depth case study material, they do not allow for more generalizable comparative data to be analysed nationally or internationally. Nonetheless, the variety of studies selected here collectively gives a thorough perspective on the research aim of this review.

\section{Pilot study yoga-mindfulness based intervention (YMBI) results}

All 30 participants voluntarily signed up for the yogamindfulness programme and willingly completed a pre and postintervention survey using the Warwick Edinburgh approach for a mental wellness questionnaire, as well as survey questions that investigated specific work-related stressors. The initial preYMBI survey using the WEWS showed the following results from participants Table 4.

Table 4: The initial pre-YMBI survey using the WEWS showed the following results from participants.

\begin{tabular}{|c|c|c|c|}
\hline $\begin{array}{c}\text { WEWS } \\
\text { Scores }\end{array}$ & Classification & $\begin{array}{c}\text { Frequency (n- } \\
\mathbf{3 0} \text { ) }\end{array}$ & Gender \\
\hline $0-32$ & $\begin{array}{c}\text { Very Low } \\
\text { Wellbeing }\end{array}$ & 06 & $\begin{array}{c}4 \text { female } 2 \\
\text { male }\end{array}$ \\
\hline $32-40$ & Below Average & 18 & $\begin{array}{c}14 \text { female } 4 \\
\text { male }\end{array}$ \\
\hline $40-59$ & Average & 04 & 4 female \\
\hline $59-70$ & Above Average & 02 & 2 female \\
\hline
\end{tabular}

( $n=30 ; 24$ females, 6 male participants) ${ }^{*} 80 \%$ of the sample reported higher scores in the same, post-YMBI survey.

Four fifths of the sample therefore self-reported at the beginning of the programme as having either very low or low wellbeing levels. The 2 respondents that reported having above-average wellbeing were regular yoga and mindfulness practitioners and welcomed the opportunity to attend classes at work. The remainder chose to join for a variety of reasons including 'high stress levels', 'time to calm down', '30 minutes to myself', and the chance to relax and breathe'. Although a small pilot sample, $80 \%$ reported an improvement in their wellbeing scores when the WEWS was taken again on the final day of the course. Those that remained the same were in the aboveaverage category to begin with. This is a huge increase and a good testimony to the effectiveness of yoga mindfulness based interventions. More detailed studies are needed to deconstruct the reasons for this increased wellbeing.

The additional Stress Causes questions asked were:

a. What things cause you the most stress at work?

b. Do you feel supported by your workplace to deal with or communicate this stress? (Please explain);

c. What could your institution do to help with stress management, and

d. Why are partaking in this programme? An additional 2 
questions were added in the post-programme survey, namely:

I. What effect has this programme had on your stress levels at work?

Table 5: Yoga-mindfulness based intervention summary responses.
II. Can you say what specifically you found effective/ ineffective? The results of these questions are shown below in Table 5.

\begin{tabular}{|c|c|}
\hline Causes of Stress at Work? & $\begin{array}{l}\text { Workload, long hours, 'never being finished', off-the record work, no time for research, ineffective } \\
\text { colleagues, administration load, bureaucracy and regulations increase, poor management, bad } \\
\text { managers, poor communication, lack of acknowledgement, undervalued, unappreciated, league } \\
\text { tables, pay does not match the expectations, trying to manage mental health of students as well } \\
\text { as our own, marking deadlines, too many students, online work, pressure to publish }\end{array}$ \\
\hline Perceptions of Support with Stress? & $\begin{array}{c}\text { 'My immediate boss has no clue', disinterest in mental health or stress overall, 'only care if } \\
\text { you take time off, no prevention or support through fair work expectations', 'they are very } \\
\text { uncomfortable with anything that is not physical illness', no system for not overloading people, or } \\
\text { avoiding breaking-points }\end{array}$ \\
\hline How can your HEI help? & $\begin{array}{l}\text { 'create fairer workloads and timetables', better administrative support for routine tasks, } \\
\text { less bureaucracy, do something about lazy colleagues, reward and acknowledge effort, allow } \\
\text { flexibility when needed, provide classes regularly not just once a year in mental health week, } \\
\text { 'listen', train managers in this, most have little empathy }\end{array}$ \\
\hline Why have you signed up for this? & $\begin{array}{l}\text { 'high stress levels', 'time to calm down', ' } 30 \text { minutes to myself', 'the chance to relax and breathe', 'I } \\
\text { already do yoga and mindfulness, it's nice to see it offered at work finally', 'so I can keep going'... }\end{array}$ \\
\hline $\begin{array}{l}\text { How has this programme helped with your } \\
\text { stress? }\end{array}$ & $\begin{array}{l}\text { 'it has been just wonderful', 'I cannot believe the difference it has made', 'I feel better able to } \\
\text { handle this place and all the nonsense now - the nonsense is still there but it seems to bother me } \\
\text { less', 'it has helped to take things a moment at a time', 'it has helped a lot, at work, but at home } \\
\text { too' 'I just feel better' }\end{array}$ \\
\hline Specifics of the programme? & $\begin{array}{l}\text { 'the breathing', 'just lying down and relaxing, especially at the end', 'I loved the yoga postures, you } \\
\text { get so knotted up sitting at your computer all day,',learning about mindfulness and how much my } \\
\text { mind jumps to the past of the future,', 'trying to practice being here now', 'just all of it, switching } \\
\text { off from work, you go back to your office feeling calmer' 'hearing others feel the same as I do' }\end{array}$ \\
\hline
\end{tabular}

\section{Discussion}

The key findings of this work presented in the previous section are enlightening in terms of stress causes in HEI employees. They are varied in terms of how they are arrived at, and sometimes contradictory in terms of outcomes and correlations (e.g. between factors such as age, gender and stress). This descriptive synthesis is an interpretation of the literature review's findings based on the reviewer's own experience and the quality and content of the selected literature [35].

What is clear is the significance attached to organisational factors in employees' experiences in the cause of stress. Some of this can be attributed arguably, to the organisation and its management, structure and funding, but wider macrosocietal forces in a global economic crisis are also at play as employability and resources become more unstable across all sectors. Nonetheless, there is repetitive and clear evidence from the papers selected that HEIs 'as organisations' are the source of stress for their own employees. Boundaries are somewhat blurred, interpretively, as to what may constitute 'personal' causes of stress. Some of the papers investigate the clearer issue of work-life balance, but others point to stress relating to individual's lack of recognition, reward, status, identity and having to deal with difficult inter-personal colleague relationships. Established literature on perceptions of stress is of relevance here (see previous sections), and adds to the complexity therefore, of making clear statements about why employees experience and/or perceive stress.

The reliability of the data cited in this review is varied, and collectively it could not be argued, in a positivist, quantitative manner that several key factors alone are convincingly and verifiably the key causes of stress across all developed nation HEIs. Qualitative research may concentrate on 'the story', whilst quantitative work may concentrate on the 'the numbers'. Fink [35] observes that when conducting a literature review, it is important not to focus solely on whether a study is qualitative or quantitative, but to concentrate instead on its accuracy and value of its findings. Bearing in mind the critiques made of each paper (CAS's), overall, it can be proposed that the majority of these studies were accurate, valid and indeed, valuable -in assessing the causes of stress in HEI employees. The findings generated as part of the YMBI pilot study follow on logically as the nextstage in research on the causes of stress in HEIs. It was evident that the programme was highly valued by the participants. All either improved or maintained their wellbeing scores based on the Warwick-Edinburgh scoring system. Many began with 
very poor levels of mental wellbeing, which is of concern - but unsurprising given the results of the literature analysis survey this paper discusses.

Taking time out seemed to be a key strategy for respondents and highly valued, even though some expressed guilt at taking half an hour 'off' work, albeit at lunchtime. There were specific perceived benefits, beyond just the time out factor, such as increased physical flexibility or un-knotting of muscles that were tense from computer work, focusing on the present moment gave relief from mental chatter and work worries, and lying down doing breath work gave a sense of calm, and slowed down stress reactions. Returning to work after each session feeling more relaxed was highly appreciated. More research is needed beyond this pilot, to assess how long the effect of a 6 week programme lasts and why these interventions work, in more detail, across a wider sample.

\section{Conclusion}

Conclusions can be drawn about the importance of clearly understanding why stress happens in Higher Education workplaces. Stress-related physical and psychological ill health is a matter of growing concern among many employees. This review has provided both qualitative, deeper understanding of actual and perceived causes of stress, as well as giving quantitative insight into the extent of the problem. The pilot study paves the way for further research on the specific types of YMBIs that may be most effective in this sector, given its specific characteristics. Educational organisations and their management and wellbeing services must take note of such findings if the quality of both education and the experience of those employed by the sector are not to be further adversely affected. The implications of this work can be examined at three levels:-

\section{Implications of findings for}

Individual employees: This review has shown that stress has negative effects on the professionalization of the HEI sector along with wellbeing, morale and personal coping abilities. Interestingly, the findings show that it is the individual's perception and understanding of organisational 'failings' that causes the most stress of all. This implies that a large majority of academic workforces are often dissatisfied, stressed and overloaded. Individuals who participate in holistic intervention programmes rate them highly and value the effects of stress reduction they deliver. Given the responsibility of academic individuals to educate societies of the future, this perhaps is a situation of rather grave concern, not just for the health of this workforce but for the impacts it may have on those they serve.

HEIs as work places: The convincing reoccurrence of critical assessment of HEIs by their own workforce as stressors, points to the need for urgent reassessment of the key factors shown to be of concern. Finance, resources, contracts and HR practices all need to be reviewed in terms of how they are targeted, how change is communicated, the effects of temporary contracts, and how employees are handled in terms of possible impacts. Much more, it seems, could be done to effectively deal with workload balances/imbalances and managing uncooperative co-workers. Poor management 'in general' seems to be a common stressor, and if this is so, practices of HR appointments, management training in dealing with employee stress and other strategies should be examined to improve matters. As it stands, the earlier literature on the benefits of academic employment are fast being eroded by this review's findings of largely ineffective organisations that lead to working conditions and workers who rank highly in stress indices.

Wider employment policy on stress: A key finding of at least two of these papers that attempted wider normative workplace stress-cause comparisons showed that at least half were common across all employment sectors (particularly finance, resources, contracts and security). However, those particular to the HEI sector, should be examined collectively by the sector to address employees concerns. How can levels of individual autonomy and the ability to research and publish be restored within burgeoning workload expectations and rising bureaucracy? How can student interactions be more positive and restored to a position of centrality rather than peripherality? How can the often qualitative aspect of equal workload sharing be balanced among diverse ability, age, experience and disciplinary colleagues? How can staff be supported by their bosses, listen to and communicated with better? These are the questions that must be addressed if academic workplace policy is to be help change the negative scenario reported in this review.

If the role of educational human resource management and of the growing wellbeing sector (such as yoga, or mindfulness based stress management) are to view personnel stress problems holistically, then a critical examination of environmental contexts, organisational structures and personal traits, perceptions and responses to those problems- is a sound approach to the deconstruction of the causes of stress. Rossen \& Cowen [36] advocate a tri-partite approach to multilayered systems of support for those working in education-'Universal wellness promotion and primary prevention' (adopted by a HEI or school), 'Targeted Prevention and Intervention' (such as group programmes like the YMBI in this paper), and 'Individual Intervention' (where specific counselling or other support is directed at identified specific staff who are in great need). These approaches need to become widespread and commonplace for improvements to happen. 
The collective research reviewed in these studies, both secondary and primary, is of significant value as a means of understanding why stress happens in the workplaces, and, importantly, begins the initial next step, in the exploration of what observations and actions should be taken regarding its impacts and future interventionist and management strategies.

\section{References}

1. Lunny M (2006) Stress Overload: A New Diagnosis. Int J Nurs Terminol Classif 17(4): 165-175.

2. Drew J, Glaser JK (1998) Defining Wellness: Stress, Illness and the Application of Existing Knowledge. Psychological Inquiry 9(1): 37-40.

3. Seyle H (1946) The general adaptation system and the diseases of adaptation. J Clin Endocrinol Metab 6: 117-230.

4. Lazarus RS (2006) Stress and Emotion: a New Synthesis. In: Lazarus RS (ed.), Psychology. ( $\left.2^{\text {nd }} e d n\right)$, Springer publishing Company, New York, USA, p. 360.

5. Cooper CL, Palmer S (2001) Conquer Your Stress. ( $2^{\text {nd }}$ edn), Chartered Institute of Personnel Development, London, UK

6. Greenberg JS (2006) Comprehensive Stress Management. ( $9^{\text {th }}$ edn), MacGraw Hill, Pennsylvania Plaza, Boston, New York City, USA.

7. Friedman M, Rosenman RH (1959) Association of Specific Overt Behaviour Pattern with Blood and Cardiovascular Findings; blood cholesterol level, blood clotting time, incidence of arcus senilis, and clinical coronary artery disease. J Am Med Assoc 169(12): 1286-1296.

8. Briggs IM, Myers PB (1980) Gifts Differing: Understanding Personality Type. Davies-Black Publishing, USA.

9. Schabracq MJ, Cooper CL (2000) The Changing Nature of Work and Stress. Journal of Managerial Psychology 15(3): 227-241.

10. Holmes S (2001) Work-Related Stress: A Brief review. J R Soc Promot Health 121(4): 230-235.

11. Anderson R (2003) Stress at Work: the Current Perspective. The Journal for the Royal Society for the Promotion of Health. 123(2): 8187.

12. Miller G, Buckholdt D, Shaw B (2008) Perspectives on Stress and Work Journal of Human Behaviour in the Social Environment 17(1-2): 1-18.

13. Winefield AH, Jarret R (2001) Occupational Stress in University Staff. International Journal of Stress Management 8(4) 285-298.

14. Gillespie NA, Walsh M, Winefields AH, Dua J, Stough C (2001) Occupational Stress in Universities: Staff Perceptions of the Causes, Consequences and Moderators of Stress. Work and Stress 15(1): 5372.

15. Tytherleigh MY, Webb C, Cooper C, Ricketts C (2005) Occupational Stress in UK Higher Education Institutions: A comparative study of all staff categories. Higher Education Research and Development 24(1): 41-61.

16. He XX, Li ZY, Shi J, Mao R, Mu RH, et al. (2000) A Comparative Study of Stress among University Faculty in China and Japan. Higher Education 39(3): 253-278.
17. Hogan, J, Carlson J, Dua J (2004) Stressors and Stress Reactions Among University Personnel. International Journal of Stress Management 9(4): 289-310.

18. Zinn KJ (2013) Full Catastrophe Living-How to cope with stress, pain and illness using mindfulness meditation. Piatkus, USA.

19. Hart R, Ivtzan I, Hart D (2013) Mind the Gap in Mindfulness Research: A Comparative Account of the Leading Schools of Thought. Review of General Psychology 17(4): 453-466.

20. Elwy AR, Groessl EJ, Eisen SV, Riley KE, Maiya M, et al. (2014) A Systematic Scoping Review of Yoga Intervention Components and Study Quality. Am J Prev Med 47(2): 220-232.

21. Smith MK, Sziva I (2017) Yoga, transformation and tourism. In: Smith MK, Puckzo L (eds.), The Routledge Handbook of Health Tourism. Routledge: Oxford University Press, UK, p. 458.

22. Kinman G, Jones F (2003) Running Up the Down Escalator: Stressors and Strains in UK Academics. Quality in Higher Education 9(1): 21-38.

23. Lazarus RS (1990) Theory-Based Stress Measurements. Psychological Inquiry 1(1): 3-13.

24. Folkman S, Lazarus RS, Gruen RJ, DeLongis A (1986) Appraisal, coping health status, and psychological symptoms. J Pers Soc Psychol 50(3): 571-579.

25. AUT -Association of University Teachers (2003) Survey of Members. Organisational Report. London.

26. Boyd S, Wylie C (1994) Workload and Stress in New Zealand Universities. Wellington: NZ Council for Educational Research, p. 104.

27. Abouserie R (1996) Stress, Coping Strategies and Job Satisfaction in University Academic Staff. Educational Psychology 16(1): 49-60.

28. Gmelch WH, Wilke PK, Lovrich NP (1986) Dimensions of Stress Among University Faculty: Factor Analytic Results from a National Study. Research in Higher Education 24(3): 266-286.

29. Tytherleigh M, Jacobs PA, Webb C, Ricketts C, Cooper C (2007) Gender, Health and Stress in English University Staff-Exposure or Vulnerability? Applied Psychology: An International Review 56(2): 267-287.

30. Blix AG, Cruise RJ, Mitchell BM, Blix GG (1994) Occupational Stress Among University Teachers. Educational Research 36(2): 157-169.

31. Quiros CH, Gemora RB (2016) Causes and effects of stress among faculty members in a state university. Asia Pacific Journal of Multidisciplinary Research 4(1): 18-27.

32. Barkhuisen N, Rothmann S (2008) Occupational Stress of Academic Staff in South African Higher Education Institutions. South African Journal of Psychology 38(2): 321-336.

33. Davie MB (2007) Doing a Successful Research Project. Pallgrave Macmillan, USA.

34. Karasek RA (1979) Job Demands, Job Decision Latitude, and Mental Strain: Implications for Job Redesign. Administrative Science Quarterly 24(2): 285-308

35. Fink A (2005) Conducting Research Literature Reviews. Sage, London, p. 265.

36. Rossen E, Cowen KC (2014) Improving mental Health in Schools. Learning and Mental Health 96(4): 8-13. 


\section{Your next submission with Juniper Publishers} will reach you the below assets

- Quality Editorial service

- Swift Peer Review

- Reprints availability

- E-prints Service

- Manuscript Podcast for convenient understanding

- Global attainment for your research

- Manuscript accessibility in different formats ( Pdf, E-pub, Full Text, Audio)

- Unceasing customer service

Track the below URL for one-step submission https://juniperpublishers.com/online-submission.php 